\title{
Cadmium and Lead in Blood Cockle (Anadara granosa) from Asajaya, Sarawak, Malaysia
}

\author{
Md. Faruk Hossen, Sinin Hamdan, and Md. Rezaur Rahman \\ Faculty of Engineering, Universiti Malaysia Sarawak, 94300 Kota Samarahan, Sarawak, Malaysia \\ Correspondence should be addressed to Md. Faruk Hossen; fhossen.chem@gmail.com
}

Received 16 July 2014; Accepted 10 October 2014; Published 4 November 2014

Academic Editor: Richard J. C. Brown

Copyright ( 2014 Md. Faruk Hossen et al. This is an open access article distributed under the Creative Commons Attribution License, which permits unrestricted use, distribution, and reproduction in any medium, provided the original work is properly cited.

The concentrations were ranged from $1.35 \pm 0.16$ to $2.22 \pm 0.34 \mu \mathrm{g} / \mathrm{g}$ (dry weight) and $2.65 \pm 0.34$ to $4.36 \pm 0.53 \mu \mathrm{g} / \mathrm{g}$ (dry weight) for $\mathrm{Cd}$ and $\mathrm{Pb}$, respectively, in blood cockle Anadara granosa from four sites of Sabang River, namely, Kampung Sambir, Kampung Tambirat, Beliong Temple, and Kampung Tanjung Apong, which are located at Asajaya, Sarawak, Malaysia. All values exceeded safety limits set by Malaysian Food Regulation (1985). It may be the cause of serious human health problems after long term consumption. Thus, consumer should have consciousness about such type of seafood from mentioned sites and need further investigation.

\section{Introduction}

The blood cockle Anadara granosa is a bivalve mollusc in the family Arcidae and subfamily Anadarinae and locally known as "kerang" in Malaysia [1]. The bivalves in this family are renowned for a source of cheap protein in tropical areas, especially in the Indo-Pacific region [2]. Therefore, marine bivalve particularly $A$. granosa is of considerable economic importance in Malaysia [3]. Since A. granosa is a filter feeding organism, contamination of the highly productive mudflats with heavy metals tends to be accumulated in their whole body tissue. This could serve as an important environmental sink of heavy metals [4] and provide an indication of river pollution.

Sarawak like West Malaysia is presently undergoing rapid industrial development and there have been incidences of toxic pollution from industry [5-7]. Asajaya is a small Sarawakian town located in the Samarahan Division and adjacent to industrial areas which were reclaimed from mangrove. The types of industry in this area presently in operation include food processing and canning, processing of agricultural products, feed mills, timber based wood products, and transport equipment. Sabang is a main river flowing into mentioned area where some fishing villages are situated and connected with Sarawak River and South China Sea. Seafood such as cockles is supplied from Asajaya to most of the seafood markets in this division. Solid and liquid wastes emanating from the industrial activities are the inevitable byproducts of manufacturing process. These wastes contain toxic chemicals and other substances including toxic heavy metals [8]. A number of natural and anthropogenic sources produce heavy metals. Heavy metals such as $\mathrm{Cd}$ and $\mathrm{Pb}$ are toxic even at relatively low concentration and not essential for metabolic activities $[9,10]$. The abundance of heavy metal may jeopardize human health due to the consumption of contaminated bivalves [11]. For examples, Cd may cause human carcinogen; $\mathrm{Pb}$ can damage blood circulation [12-14].

People are becoming more aware of the complexity of the nature and the delicate balance that exist within the global ecosystem [15]. The discharge of effluents and associated toxic compounds into aquatic systems represents an ongoing environmental problem due to their possible impact on communities in the receiving aquatic water and a potential effect on human health [16]. In particular, in highly polluted and industrial areas, point and nonpoint sources of anthropogenic chemicals and metals have polluted rivers with highly complex mixtures of chemicals and other anthropogenic perturbations to degree where life in rivers is 


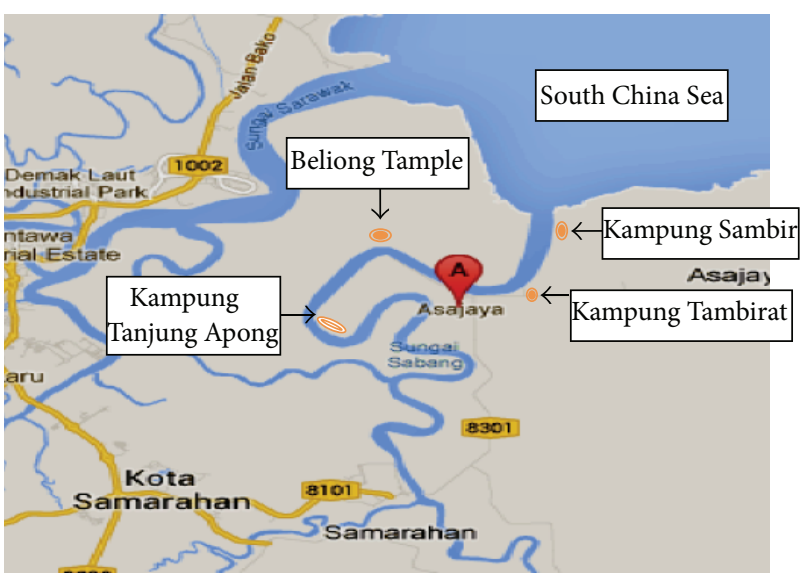

FIGURE 1: Map of Asajaya showing sampling sites.

severely impacted [17]. Therefore, the objective of this study has been to determine the concentrations of two toxic metals $(\mathrm{Cd}$ and $\mathrm{Pb})$ in blood cockles sampled from four different sites near Sabang River of Asajaya.

\section{Method and Materials}

2.1. Description of Study Sites. The blood cockles Anadara granosa were collected during May 14 from four sites of Sabang River, namely, Kampung Sambir, Kampung Tambirat, Beliong Temple, and Kampung Tanjung Apong, which are located at Asajaya, Sarawak, Malaysia, as shown in Figure 1. Sabang is a main river flowing into mentioned area where some fishing villages are situated. This river is connected with Sarawak River and with South China Sea. The sites are located adjacent to industrial areas which were reclaimed from mangrove. Currently, the types of industries are food processing and canning, processing of agricultural products, feed mills, timber based wood products, and transport equipment.

2.2. Sampling and Metal Analysis. Cockles were transported, refrigerated at $4^{\circ} \mathrm{C}$, to the laboratory within $4 \mathrm{~h}$ of collection. After a preliminary shell clean-up, the specimens were frozen and maintained at $-18^{\circ} \mathrm{C}$ pending processing. For analysis, all individuals from one site were defrosted; the shells were carefully removed using Teflon-covered forceps and a stainless steel surgical blade; the soft tissues were then freeze-dried at $-80^{\circ} \mathrm{C}$ for about $24 \mathrm{~h}$. These dried samples were then ground to obtain a homogenous powder and stored separately in acid-cleaned glass bottles in desiccators at room temperature until analysis. Approximately $0.5 \mathrm{~g}$ of the samples was digested with $10 \mathrm{~mL}$ of $65 \%$ analytical grade $\mathrm{HNO}_{3}$ into a microwave digestion vessel and it was then capped tightly. The digestion vessel (bomb) was then placed in a normal, conventional microwave oven and cooked for two minutes at a $40 \%$ power level. The vessel was then cooled for five minutes and then recooked for four minutes at $30 \%$ power level. The completely digested sample was then allowed to cool until the fumes dissipated. The inner side of
TABLE 1: The concentrations ( $\mu \mathrm{g} / \mathrm{g}$ dry wt) of $\mathrm{Cd}$ and $\mathrm{Pb}$ in blood cockle Anadara granosa from four sites of Sabang River at Asajaya, Sarawak, Malaysia.

\begin{tabular}{lcc}
\hline Sampling sites & $\begin{array}{c}\mathrm{Cd} \\
(\mathrm{mean} \pm \mathrm{SD})\end{array}$ & $\begin{array}{c}\mathrm{Pb} \\
(\mathrm{mean} \pm \mathrm{SD})\end{array}$ \\
\hline Kampung Sambir & $1.85 \pm 0.28$ & $3.55 \pm 0.48$ \\
Kampung Tambirat & $1.35 \pm 0.16$ & $2.65 \pm 0.34$ \\
Beliong Temple & $1.58 \pm 0.23$ & $2.94 \pm 0.42$ \\
Kampung Tanjung Apong & $2.22 \pm 0.34$ & $4.36 \pm 0.53$ \\
$\begin{array}{l}\text { The maximum permissible limits set } \\
\text { by Malaysian Food Regulations (1985) }\end{array}$ & $\mathbf{1 . 0 0}$ & $\mathbf{2 . 0 0}$ \\
\hline
\end{tabular}

SD: standard deviation.

the cap was then cleaned with distilled water and the washed liquid was added to the original sample mixture in the vessel and then it was subjected to filtration using number \#44 Whatman filter paper. The sample solution was diluted to a $50 \mathrm{~mL}$ graduated volumetric flask and then subjected to metal determination.

Flame atomic absorption spectrometer (FAAS; PerkinElmer HGA-600) was employed for the analysis of cadmium and lead. Standard mixtures of 0.05, 0.1, 0.2, 0.5, and $1.0 \mathrm{ppm}$ of $\mathrm{Cd}$ and $\mathrm{Pb}$ were prepared in nitric acid solution for calibration. The accuracy of the methods was assessed using certified reference material DORM-2 in triplicate, and mean recovery was $95.5 \pm 1.3 \%$ for both metals. All data were expressed on a dry weight basis ( $\mu \mathrm{g} / \mathrm{g}$ dry wt.).

\section{Results and Discussion}

It was observed that the concentrations ranges were $1.35 \pm$ 0.16 to $2.22 \pm 0.34 \mu \mathrm{g} / \mathrm{g}$ (dry weight) and $2.65 \pm 0.34$ to $4.36 \pm 0.53 \mu \mathrm{g} / \mathrm{g}$ (dry weight) for $\mathrm{Cd}$ and $\mathrm{Pb}$, respectively, in cockles (Table 1). The highest values $(2.22 \pm 0.34 \mu \mathrm{g} / \mathrm{g}$ for $\mathrm{Cd}$ and $4.36 \pm 0.53 \mu \mathrm{g} / \mathrm{g}$ for $\mathrm{Pb}$ ) were observed in specimens from Kampung Tanjung Apong which is located near the connecting point of Sabang River and Sarawak River and the second highest values $(1.85 \pm 0.28 \mu \mathrm{g} / \mathrm{g}$ for $\mathrm{Cd}$ and $3.55 \pm 0.48 \mu \mathrm{g} / \mathrm{g}$ for $\mathrm{Pb}$ ) were observed from Kampung Sambir which is located near the connecting point of Sabang River and China Sea. The levels of $\mathrm{Cd}$ and $\mathrm{Pb}$ from studied sites exceeded the maximum permissible limits set by Malaysian Food Regulations (1985).

The highest value of $\mathrm{Cd}$ may be due to the influence of external discrete sources like industrial activities, agriculture runoff and other anthropogenic inputs $[11,18]$ and sites are within the vicinity of agricultural areas mostly large oil palm plantations heavy in pesticides and herbicides used $[5,19]$. After long term consumption, this may be the cause of possible toxicological risks and heavy metal related diseases, such as Parkinson's and Wilson's diseases [20]. On the other hand, the highest value of $\mathrm{Pb}$ may result from burning of fossil fuels from boats used for fishing and also leisure activities [6, 21]. This may be the cause of neurological deficits such as mental retardation in children and kidney disease such as interstitial nephritis to adults and also contribute to hypertension and cardiovascular disease [22] to the consumers after long term 
consumption. Previous study from the northwest coast of Peninsular Malaysia, in the state of Penang, showed that the levels of heavy metals analyzed for cockles A. granosa were ranged from 0.87 to 0.89 and 0.11 to $0.12 \mu \mathrm{g} / \mathrm{g}$ dry weights for $\mathrm{Cd}$ and $\mathrm{Pb}$, respectively [23]. The results indicate that the levels of $\mathrm{Cd}$ and $\mathrm{Pb}$ in $A$. granosa from Penang were lower than safety limits set by Malaysian Food Regulations (1985) as well as lower than those obtained in this research findings. Another research revealed that the levels of heavy metals analyzed for green-lipped mussels Perna viridis collected along the west coast of Peninsular Malaysia were ranged from 0.68 to 1.25 and 2.51 to $8.76 \mu \mathrm{g} / \mathrm{g}$ dry weights for $\mathrm{Cd}$ and $\mathrm{Pb}$, respectively [24]. The concentration of $\mathrm{Cd}$ was below the reference values for human consumption set by Malaysian Food Regulations (1985) whereas the concentration of $\mathrm{Pb}$ was above the reference values. The results also indicate that the level of $\mathrm{Pb}$ in the present investigation was within the value from the west coast of Peninsular Malaysia. The use of coastal waters as a convenient receptacle for domestic and industrial wastes threatens the quality of seafood rivers and coastal waters are presently exposed to not only the increasing quantities of metals and nutrients, but also the cocktails of industrial derived contaminants, many of which exhibit significant persistence and capabilities for bioaccumulation [25].

However, it revealed that the cockles in this research area have been contaminated through $\mathrm{Cd}$ and $\mathrm{Pb}$ caused by agriculture runoff and industrial and other anthropogenic activities which can be the cause of serious human health problems for long term consumption.

\section{Conclusion}

It is concluded that the concentrations of $\mathrm{Cd}$ and $\mathrm{Pb}$ in blood cockles from four sites of Asajaya exceeded the maximum permissible limits set by Malaysian Food Regulation (1985). It showed that cockles from the mentioned area have been contaminated through $\mathrm{Cd}$ and $\mathrm{Pb}$ caused by agriculture runoff and industrial and other anthropogenic activities. It may be the cause of serious human health problems such as Parkinson's and Wilson's diseases and also mental retardation in children and kidney disease such as interstitial nephritis to adults and also contribute to hypertension and cardiovascular disease after long term consumption. Thus, consumer should have consciousness about such type of seafood from mentioned sites and need further investigation.

\section{Conflict of Interests}

The authors declare that there is no conflict of interests.

\section{Acknowledgments}

The authors wish to acknowledge the financial assistance provided through the Malaysian Government Research Grant no. ERGS/02(08)860/2012(12) and by the University Malaysia Sarawak (UNIMAS).

\section{References}

[1] N. Ibrahim, "Trace element content of Malaysian cockles (Anadara granosa)," Food Chemistry, vol. 54, no. 2, pp. 133-135, 1995.

[2] J. E. Bardach, J. H. Ryther, and W. O. McLarney, Aquaculture: The Farming and Husbandry of Freshwater and Marine Organisms, Wiley-Interscience, New York, NY, USA, 1972.

[3] V. Simeonov, D. L. Massart, G. Andreev, and S. Tsakovski, "Assessment of metal pollution based on multivariate statistical modeling of "hot spot" sediments from the Black Sea," Chemosphere, vol. 41, no. 9, pp. 1411-1417, 2000.

[4] W. X. Liu, X. D. Li, Z. G. Shen, D. C. Wang, O. W. H. Wai, and Y. S. Li, "Multivariate statistical study of heavy metal enrichment in sediments of the Pearl River Estuary," Environmental Pollution, vol. 121, no. 3, pp. 377-388, 2003.

[5] D. Kanakaraju, F. Ibrahim, and M. N. Berseli, "Comparative study of heavy metal concentra-tions in razor clam (Solen regularis) in Moyan and Serpan, Sarawak," Global Journal of Environmental Research, vol. 2, no. 2, pp. 87-91, 2008.

[6] D. Kanakaraju, J. Connie, and S. M. Long, "Heavy metal concentrations in the razor clam (Solen Spp) from Muara Tebas, Sarawak," The Malaysian Journal of Analytical Sciences, vol. 12, no. 1, pp. 53-58, 2008.

[7] N. A. M. Yusoff and S. M. Long, "Comparative bioaccumulation of heavy metals $(\mathrm{Fe}, \mathrm{Zn}, \mathrm{Cu}, \mathrm{Cd}, \mathrm{Cr}, \mathrm{Pb})$ in different edible mollusk collected from the estuary area of Sarawak River," in Proceedings of the Universiti Malaysia Terengganu 10th International Annual Symposium (UMTAS '11), LSP136, Kuala Terengganu, Malaysia, July 2011.

[8] S. R. Tariq, M. H. Shah, N. Shaheen, A. Khalique, S. Manzoor, and M. Jaffar, "Multivariate analysis of trace metal levels in tannery effluents in relation to soil and water: a case study from Peshawar, Pakistan," Journal of Environmental Management, vol. 79, no. 1, pp. 20-29, 2006.

[9] L. Rojas de Astudillo, I. Chang Yen, and I. Bekele, "Heavy metals in sediments, mussels and oysters from Trinidad and Venezuela," Revista de Biologia Tropical, vol. 53, no. 1, pp. 41-53, 2005.

[10] B. Y. Kamaruzzaan, M. S. Mohd Zahir, B. Akbar John et al., "Bioaccumulation of some metals by Green mussel Perna viridis (Linnaeus 1758) from Pekan, Pahang, Malaysia," International Journal of Biological Chemistry, vol. 5, no. 1, pp. 54-60, 2011.

[11] K. Lias, T. Jamil, and S. N. Aliaa, "A preliminary study on heavy metal concentration in the marine bivalves Marcia marmorata species and sediments collected from the coastal area of Kuala Perlis, North of Malaysia," IOSR Journal of Applied Chemistry, vol. 4, no. 1, pp. 48-54, 2013.

[12] IARC (International Agency for Research on Cancer), IARC Monographs on the Evaluation of Carcinogenic Risks to Humans, vol. 58 of Cadmium and Cadmium Compounds, Lyon, France, 1993.

[13] M. S. Rahman, A. H. Molla, N. Saha, and A. Rahman, "Study on heavy metals levels and its risk assessment in some edible fishes from Bangshi River, Savar, Dhaka, Bangladesh," Food Chemistry, vol. 134, no. 4, pp. 1847-1854, 2012.

[14] N. Arnich, V. Sirot, G. Rivière et al., "Dietary exposure to trace elements and health risk assessment in the 2nd French Total Diet Study," Food and Chemical Toxicology, vol. 50, no. 7, pp. 2432-2449, 2012. 
[15] A. Demirak, F. Yilmaz, A. Levent Tuna, and N. Ozdemir, "Heavy metals in water, sediment and tissues of Leuciscus cephalus from a stream in Southwestern Turkey," Chemosphere, vol. 63, no. 9, pp. 1451-1458, 2006.

[16] V. Canivet and J. Gibert, "Sensitivity of epigean and hypogean freshwater macroinvertebrates to complex mixtures. Part I: laboratory experiments," Chemosphere, vol. 46, no. 7, pp. 9991009, 2002.

[17] R. Smolders, W. de Coen, and R. Blust, "An ecologically relevant exposure assessment for a polluted river using an integrated multivariate PLS approach," Environmental Pollution, vol. 132, no. 2, pp. 245-263, 2004.

[18] A. M. Rabee, Y. F. Al-Fatlawy, A. H. Najim, and M. Nameer, "Using Pollution Load Index (PLI) and geoaccumulation index (I-Geo) for the assessment of heavy metals pollution in Tigris river sediment in Baghdad Region," Journal of Al-Nahrain University, vol. 14, no. 4, pp. 108-114, 2011.

[19] A. M. Yusof, N. F. Yanta, and A. K. H. Wood, "The use of bivalves as bio-indicators in the assessment of marine pollution along a coastal area," Journal of Radioanalytical and Nuclear Chemistry, vol. 259, no. 1, pp. 119-127, 2004.

[20] E. B. Montgomery Jr., "Heavy metals and the etiology of Parkinson's disease and other movement disorders," Toxicology, vol. 97, no. 1-3, pp. 3-9, 1995.

[21] F. B. Edward, C. K. Yap, A. Ismail, and S. G. Tan, "Interspecific variation of heavy metal concentrations in the different parts of tropical intertidal bivalves," Water, Air, and Soil Pollution, vol. 196, no. 1-4, pp. 297-309, 2009.

[22] WHO (World Health Organization), Lead: International Programme on Chemical Safety (IPCS), WHO Food Additives Series 44, WHO, Geneva, Switzerland, 2000.

[23] F. M. A. Alkarkhi, N. Ismail, and A. M. Easa, "Assessment of arsenic and heavy metal contents in cockles (Anadara granosa) using multivariate statistical techniques," Journal of Hazardous Materials, vol. 150, no. 3, pp. 783-789, 2008.

[24] C. K. Yap, A. Ismail, and S. G. Tan, "Heavy metal (Cd, Cu, Pb and $\mathrm{Zn}$ ) concentrations in the green-lipped mussel Perna viridis (Linnaeus) collected from some wild and aquacultural sites in the west coast of Peninsular Malaysia," Food Chemistry, vol. 84, no. 4, pp. 569-575, 2004.

[25] C. N. Sawyer, P. L. Mc Carty, and G. F. Parkin, Chemistry for Environmental Engineering, McGraw-Hill International, New York, NY, USA, 4th edition, 1994. 

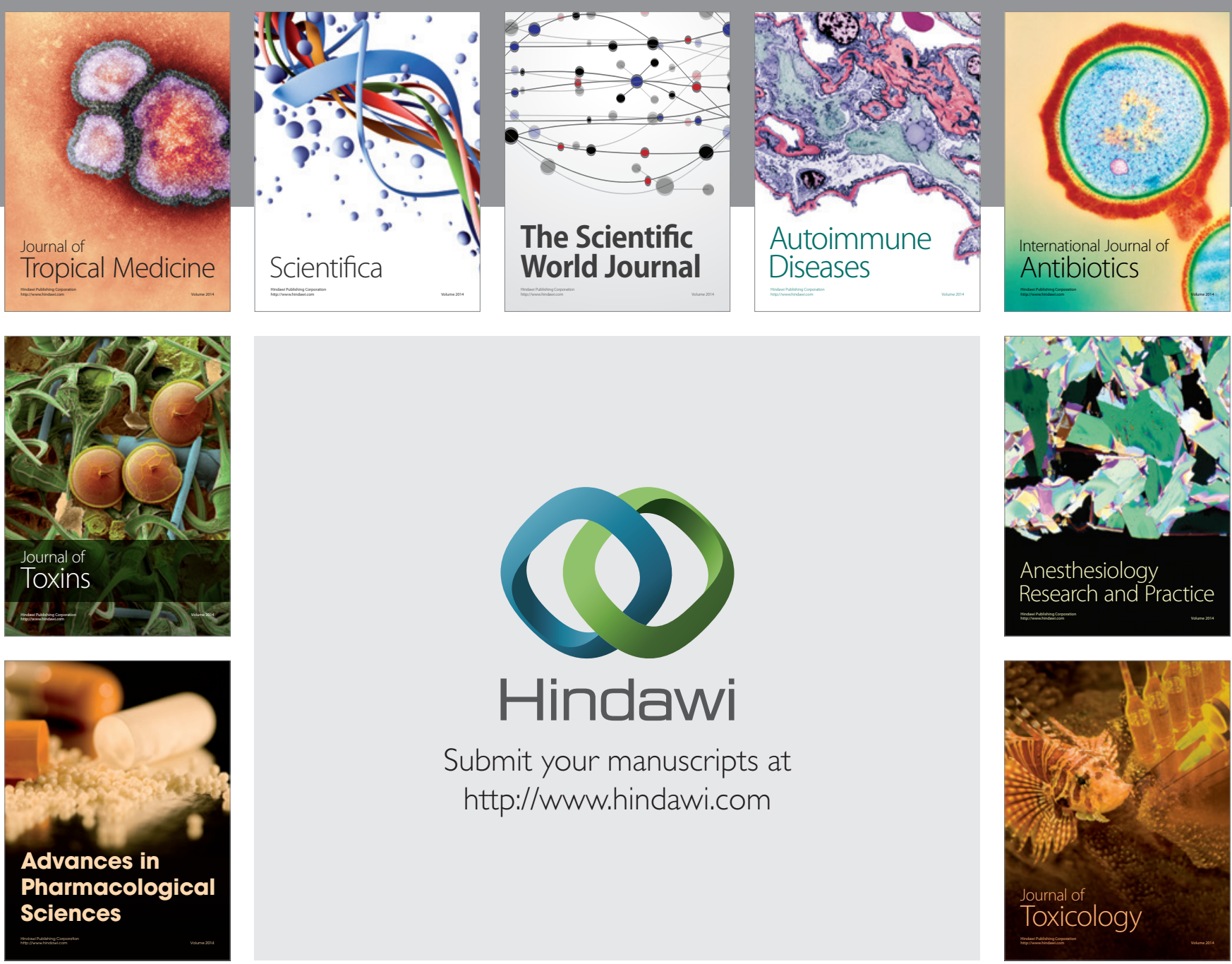

\section{Hindawi}

Submit your manuscripts at

http://www.hindawi.com
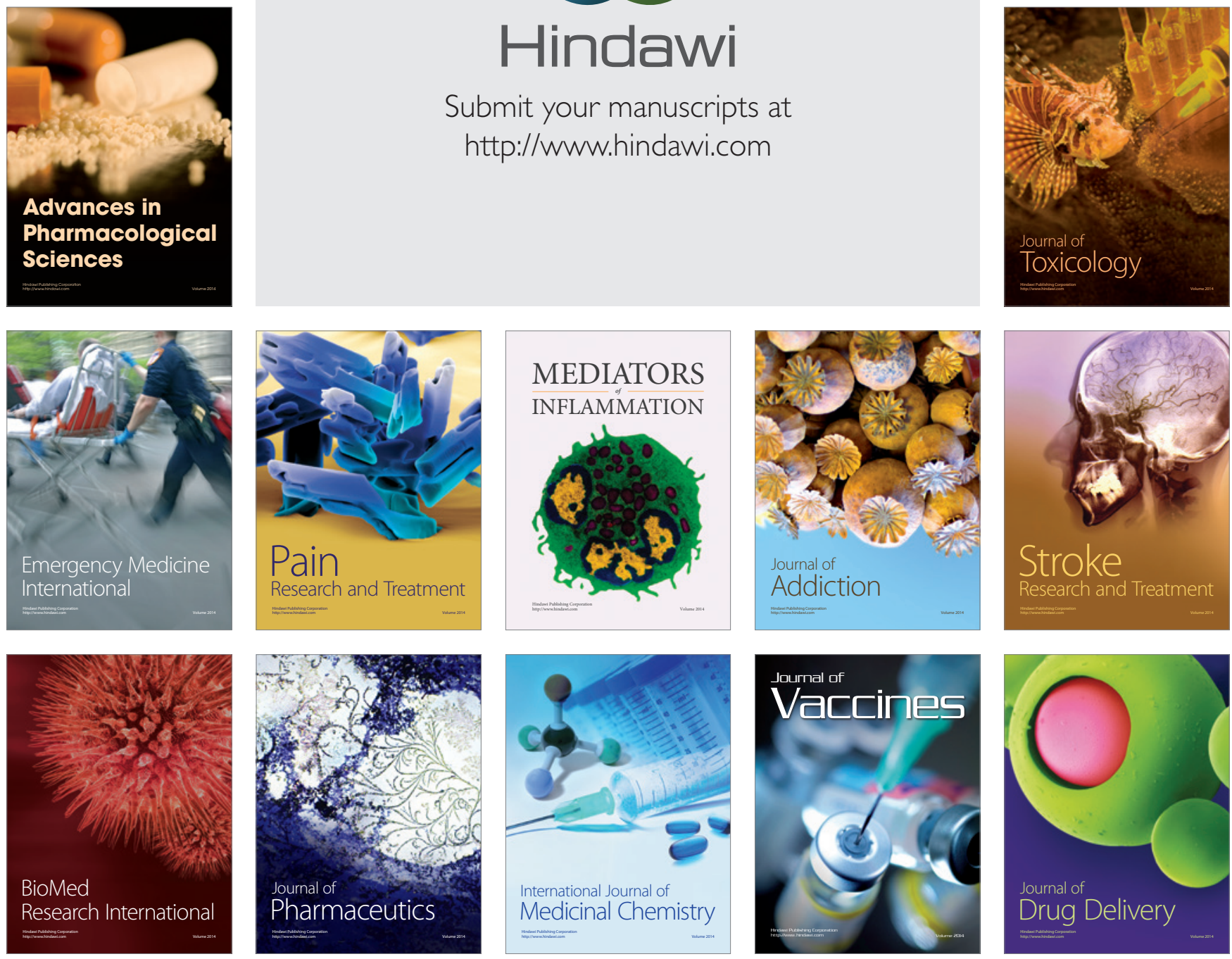